\title{
FOOD SAFETY AND COMPETENCIES OF LABORATORY EMPLOYEES IN ORGANIC FOOD PROCESSING
}

doi: $\quad 10.2478 /$ czoto-2019-0075

Date of submission of the article to the Editor: $11 / 11 / 2018$

Date of acceptance of the article by the Editor: 29/12/2018

Szymon T. Dziuba ${ }^{1}$ - orcid id: 0000-0002-6509-5843

Manuela Ingaldi ${ }^{2}$ - orcid id: 0000-0002-9793-6299

Eva Hamplová ${ }^{3}$ - orcid id: 0000-0002-4314-873X

Anna Cierniak-Emerych ${ }^{1}$ - orcid id: 0000-0003-4435-4954

${ }^{1}$ Wroclaw University of Economics, Poland, szymon.dziuba@ue.wroc.pl

${ }^{2}$ Czestochowa University of Technology, Poland, manuela.ingaldi@wz.pcz.pl, manuela@gazeta.pl

${ }^{3}$ University of Hradec Králové, Czech Republic

Abstract: Food safety means all the conditions that have to be met and actions that have to be taken at all stages of food production or sales to protect human health and life. Studies have demonstrated that organic food is considered by consumers to be healthier and safer than conventional food produced by means of intensive farming methods. In this context, the interest in organic food among both consumers and distributors is increasing. This means that there are many factors determining organic food production. Among them are those related to competencies that affect product safety, which represents a guarantee that the enterprise will achieve market success and is one of the sources of competitiveness for such enterprises.

Therefore, the aim of the study was to present assessment of soft competencies of laboratory employees by their immediate superiors. The problem was identified more closely as a case study of the corporation that produces organic foods, whereas assessment of competencies was compared to the specific features of the food sector the enterprise operates in, with the examples of the branches located in Poland, the Czech Republic and Romania.

Keywords: ecology, food safety, competencies.

\section{INTRODUCTION}

Organic food production represents one of the fastest developing sectors in the European Union. According to a report published in 2018 by the International Federation of Organic Agriculture IFOAM, world organic food market soared to over 90 billion euro, and, in Europe alone, it reached over 35 billion euro, of which ca. 167 million euro was recorded in Poland, ca. 79 million euro in the Czech Republic, and ca. 80 million euro in Romania. It is worth emphasizing that this value is steadily growing year by year (IFOAM Report, 2018) and contributes to the development of the sectors that support this market (Kadłubek, 2016). Customers' perception of 
organic food as healthier and tastier has a significant impact on the development of the market of such products. Meeting customers' expectations concerning the quality and values of organic food stimulates not only primary production (and therefore development of organic farming) but also generation of specialized organic processing plants. In recent years, the number of such plants has been steadily increasing by several dozen percent a year, reaching 558 in the Czech Republic, 562 in Poland, and 139 in Romania in 2015 (IJHARS, 2017).

Importantly, a principle is used in organic production that processing of raw materials can be performed to the extent necessary in order not to reduce the biological value of products. Processing of organic products is aimed to preserve a high biological quality of the raw materials. Therefore, only traditional mechanical, physical and fermentation methods are allowed, whereas the number of permissible additives is limited. It should be stressed that the basic criterion that determines the quality of organic food is that such commodities are produced in an organisation that complies with the principles contained in the relevant legal acts. To meet this criterion, current legislation places a great emphasis on the methods and conditions in which food (both of plant and animal origins) is produced (Dziuba and Ingaldi, 2016).

Therefore, organic processing in the European Union is regulated in a number of legal regulations that are binding for all EU member states. The most important legal acts regulating the activities in this area in the Community include:

- Council Regulation (EC) No 834/2007 of 28 June 2007 on organic production and labelling of organic products and repealing Regulation (EEC) No 2092/91 (OJ L 189 of 20 July 2007 p.1), as amended.

- Commission Regulation (EC) No 889/2008 of 5 September 2008 laying down detailed rules for the implementation of Council Regulation (EC) No 834/2007 on organic production and labelling of organic products with regard to organic production, labelling and control (OJ L 250 of 18 September 2008 p.1), as amended.

- Commission Regulation (EC) No 1235/2008 of 8 December 2008 laying down detailed rules for implementation of Council Regulation (EC) No $834 / 2007$ as regards the arrangements for imports of organic products from third countries.

- Commission Regulation (EC) No 1254/2008 of 15 December 2008 amending Commission Regulation (EC) No 889/2008 laying down detailed rules for the implementation of Council Regulation (EC) No 834/2007 on organic production and labelling of organic products with regard to organic production, labelling and control.

It is also worth quoting Commission Regulation (EU) 271/2010 of 24 March 2010, which introduced the EU organic production logo termed Euro-leaf on 1 July 2010 (Commission Regulation (EU) No 271/2010; http://www.eu-organic-food.eu). On 1 July 2012, the obligation was introduced to place this logo on the packaging of organic foods produced by producers in the member states.

The European organic food logo helps consumers verify the origin and quality of the food. The presence of this logo on any food product means that the product complies with the requirements of the EU organic farming legislation.

These regulations place great emphasis on the control and shift responsibility for the credibility of organic products to the producer. The entire production process is 
assessed by the certification body. The operations in an organic processing company are also significantly affected by the systems for ensuring safety of food production. Using such systems results from current legal provisions. Similar to conventional processing facilities, organic processing plants have to meet all sanitary and technical requirements. Therefore, production of organic food is performed in accordance with the provisions of the respective food safety management systems, such as the Good Hygienic Practice - GHP, Good Manufacturing Practice - GMP, HACCP, or the ISO 22000 standard. It should be stressed that all processes used for the production of such food are assessed and monitored according to the principle 'from field to table'. It is particularly important to ensure health security of food. Therefore, crop protection agents, which reduce the risk of biological threats, are not applied (Mazur et al., 2016). It is worth noting that customer satisfaction and meeting their expectations concerning safe and healthy products impact on the corporate image. Optimisation of the quality of organic products to meet the requirements is conducive to consumer attachment to a specific product or brand (Łukasiński, 2008).

These aspects, related to the specific activities of enterprises that process organic foods, force these entities to employ competent staffs at both management and executive levels.

\section{CHARACTERISTICS OF COMPETENCIES OF ORGANIC FOOD MILL EMPLOYEES: RESEARCH METHODOLOGY}

Competencies define knowledge, attitudes and skills of a person that allow him or her to perform professional assignments at the appropriate level, depending on the nature and scope of the tasks and customer expectations. Employee competencies can be characterized by referencing to their personal traits, motives for action, skills, selfesteem, perception of social roles, knowledge, etc. (Rakowska, 2007; Filipowicz, 2004; Oleksyn, 2010; Kotus et al., 2016).

The nature and type of employee competencies is a factor influencing quality, efficiency and, importantly, occupational safety (Womack, et al., 1990; Zivaljevic, 2015; Tate et al., 2009).

Analysis of the definitions of competencies used by different authors reveals that they are complementary to each other and have a significant impact on the functioning of the organization and gaining a competitive advantage in the global market. Nowadays, systems of values in organisations are changing, with each employee expected to contribute to generating value for the customer. Thus, the emphasis in management is increasingly placed on employee competencies and their continuous development through, among other things, effective motivation of employees (Pietron'Pyszczek, 2015; Maszke et al., 2018; Wolniak et al., 2018). The objectives for the development of employee competencies are determined by the needs of enterprises, including organic processing, resulting from the adopted mission, long-term goals, and the organization's relations with the closer and further business environments (Lendzion and Stankiewicz-Mróz, 2005; Dulska et al. 2017). In this context, the following division should be presented:

- professional competencies, identified with hard competencies,

- personal competencies, termed soft competencies, which are associated with the ability to think strategically, analytically and creatively, good work organisation, willingness and ability to acquire new competencies, and resistance to stress (Katana, 2016). 
In organic processing, key values such as teamwork, creativity and sense of responsibility are very important in the ever-changing business environment, with the major focus on meeting customer needs. In this context, a study published by $\mathrm{M}$. Robles seems to be interesting. His research identified a group of ten most important soft competencies of employees relevant from the point of view of employers in the organic processing sector (Robles, 2012; Krynke et al., 2014):

- flexibility, integrity, communication skills, politeness, teamwork, responsibility, professionalism, positive attitude, work ethic, interpersonal skills.

The issues of employee competencies according to M. Robles were analysed in more detail by referring to the related literature, current legislation, international statistical data and authors' own empirical research in the form of the analyses of the data from the materials derived from the surveyed entities such as organic processing companies affiliated by capital and technology within one group and located in the Czech Republic, Poland and Romania. The analysis concerned industrial mills with a long tradition, which, after successful certification process, produce organic flour.

With the qualitative nature of the presented problem, the case study method was used for empirical studies. The survey was performed as structured interviews. The interviews were conducted in 2017 and 2018. The five-step Likert scale was used. Respondents were 27 laboratory employees from the three countries. The above classification of soft competencies was used for the analysis in the enterprises surveyed.

\section{ANALYSIS OF SOFT COMPETENCIES OF EMPLOYEES: RESULTS OF EMPIRICAL RESEARCH}

The structure of the laboratory staff was as follows:

- In the Czech Republic - 8 people,

- In Poland - 9 people,

- In Romania - 10 people.

The respondents, i.e. direct superiors, assessed their employees on a scale of 1 to 5 points in relation to the soft competencies enumerated by $M$. Robles. The competencies were analysed with respect to laboratory employees from the Czech Republic, Poland and Romania, as shown in Table 1.

Table 1 shows the level of competencies of laboratory employees from the Czech Republic, Poland and Romania.

The first column, concerning the assessment performed by the Czech superior, shows that flexibility and integrity are the lowest among the soft competencies of his subordinates. The level of teamwork is also insufficient, although it is much valued and appreciated in the labour market today. Positive attitude is satisfactory, whereas responsibility, interpersonal skills, work ethic and professionalism were assessed at a high level.

The data on Polish laboratory employees clearly show that their positive attitude is low $(44.3 \%)$ or very low (33.3\%). The level of flexibility is not the best in this group of employees and assessed as high (22.2\%) and very high (11.1\%). It should be emphasized that flexibility in the companies surveyed is a trait that is very important and even critical in periods of intensive seasonal works (harvest). The level of competencies related to professionalism, responsibility and teamwork was rated highly. 
Table 1.

Assessment of soft competencies of laboratory employees by their superiors

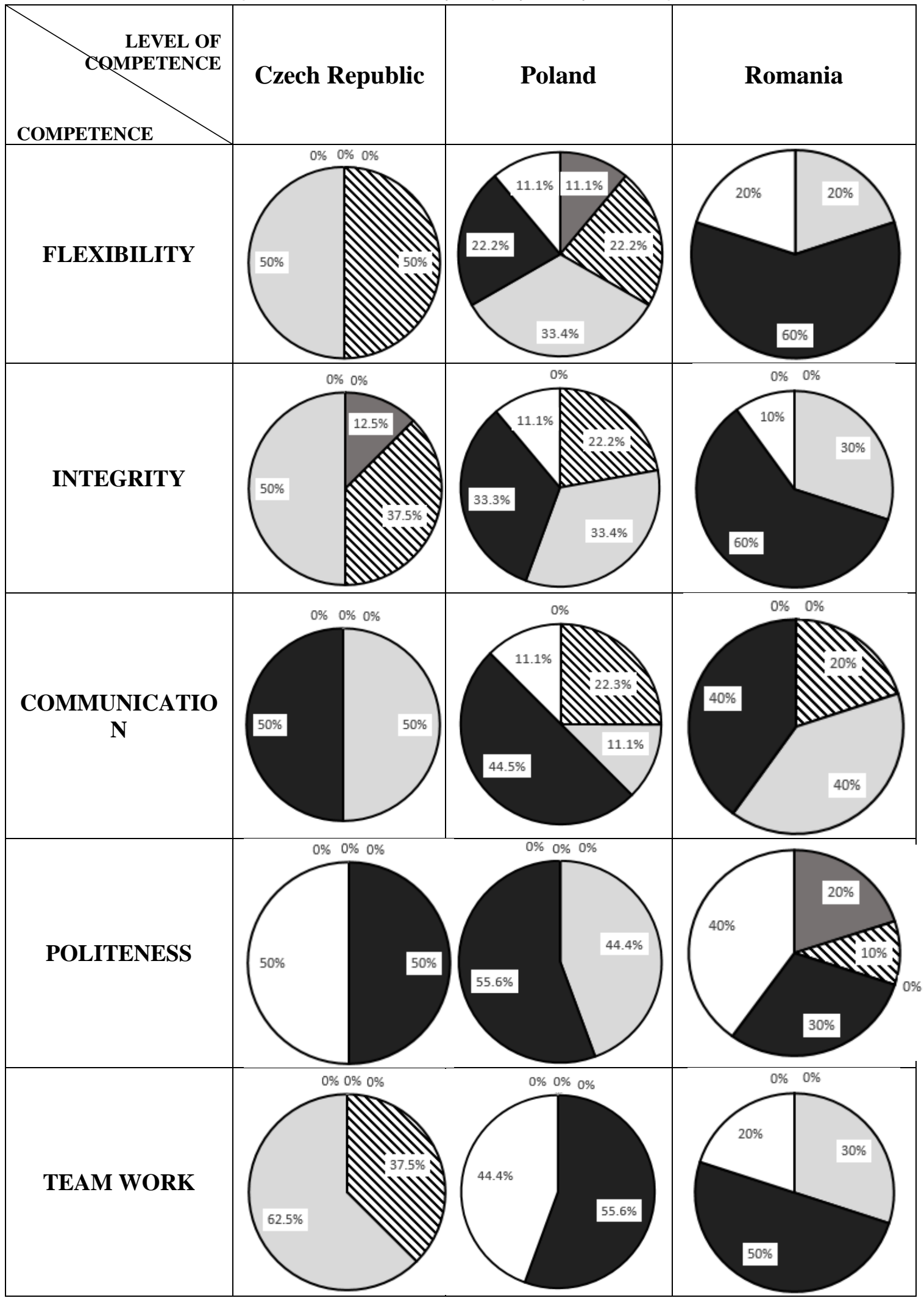




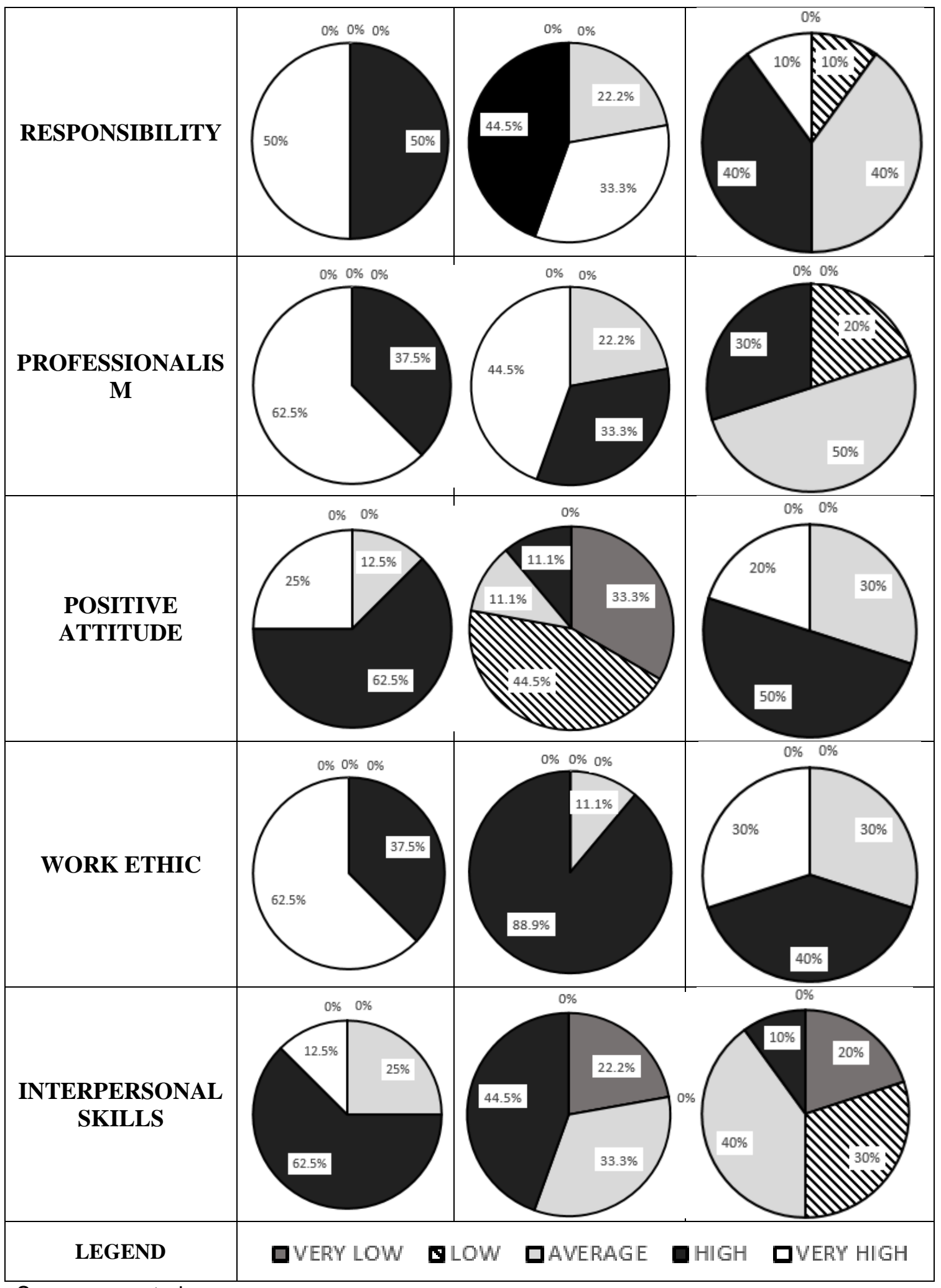

Source: own study

In Romania, integrity, flexibility, teamwork, positive attitude and work ethics of the laboratory employees were assessed as satisfactory. Low communication skills and not very high level of professionalism were considered to be the weakness of the employee competencies. When interpreting the results of the study, the managers 
also emphasized the presence of significant deficiencies in the area of interpersonal skills.

\section{CONCLUSION}

The laboratory employees surveyed should be characterized by knowledge and skills needed to examine samples of raw materials and products for physico-chemical analyses in order to verify whether the products are free from contaminants and residues of prohibited substances, and to assess product quality and compare the results with the applicable standards, since food producers are responsible for providing the consumer with comprehensive information on the quality and origin of the product, which in turn improves the competitiveness of organic food. It is therefore required that laboratory staff is familiar with, among other things, detailed requirements for food processing according to Articles 19 and 23 of the Regulation (EC) 834/2007, Articles 26, 27, 31 and 35, and those contained in the Annex VIII of the implementing rules (Reg. 889/2008). Bearing in mind the nature of the work performed, the competencies of employees surveyed include professionalism, teamwork and work ethic.

Considering the statistical data concerning the food processing companies surveyed, a substantial development can be observed in this sector. This has an impact on the demand for qualified and efficient employees in each department of such companies that can meet the challenges contained in legal regulations, good manufacturing or laboratory practices and, most importantly, customer expectations. Sources of employee effectiveness, also including soft competencies, are of key importance to gaining a competitive advantage.

Analysis of Table 1 reveals that improvement measures should be taken to increase the level of soft competencies through the implementation of tailored training programmes and courses in areas where such competencies have to be supplemented and extended. The analyses presented in this study showed that the level of competencies of the employees from the Czech Republic, Poland and Romania varies, and, therefore, implementation of dedicated training programs is recommended in this area.

\section{References}

Commission Regulation (EU) No 271/2010 of 24 March 2010 amending Regulation (EC) No 889/2008 laying down detailed rules for the implementation of Council Regulation (EC) No 834/2007 as regards the organic production logo of the EU.

Dulska, A., Studnicki, A., Szajnar, J., 2017. Reinforcing cast iron with composite insert. Archives Of Metallurgy And Materials, 62, 1, 355-357.

Dziuba, S.T., Ingaldi, M., 2016. Characteristics of the Organic Products Market in Poland. 16th International Multidisciplinary Scientific GeoConference (SGEM 2016), Albena, Bułgaria. Book 5. Ecology, Economics, Education and Legislation. Vol.3. Environmental Economics, s. 71-78.

Filipowicz, G., 2004. Zarządzanie kompetencjami zawodowymi. PWE, Warszawa, Poland.

http://www.eu-organic-food.eu (10.09.3028).

IFOAM Report. 2018. The World of Organic Agriculture Statistics \& Emerging Trends, ISBN PDF version 978-3-03736-068-2, p. 146-147, 327-329. 
IJHARS. 2017. Główny Inspektorat Jakości Handlowej Artykułów RolnoSpożywczych. Warsaw. Raport o stanie rolnictwa ekologicznego w Polsce w latach 2015-2016, p. 66.

Kadłubek, M., 2017. Selected Issues of Management of Green Logistics in Transport Sector. International Conference on Communication. Management and Information Technology 2016 (ICCMIT'16), Shaping the Future of ICT. Trends in Information Technology, Communications Engineering, and Management, Eds. I. M.M. El Amary, A. Brzozowska, Wyd. CRC Press Taylor \& Francis Group, Boca Raton 2017, 413-424.

Katana, K., 2016. Innowacje $w$ przedsiębiorstwie w kontekście kompetencji miękkich pracowników. Zeszyty Naukowe Politechniki Śląskiej, Seria: Organizacja i Zarządzanie, 95, 163-165.

Kotus, M., Jankajová, E., Lestyánszka Škůrková, K., Matisková, D., Zach, M., 2016. Safety audit of band saw in manufacturing organization. Acta Universitatis Agriculturae et Silviculturae Mendelianae Brunensis. 64, 2, 467-471.

Krynke, M., Knop, K., Mielczarek, K., 2014. An identification of variables that influences on the manufactured products quality. Production Engineering Archives, 4/3, 22-25.

Lendzion, J. P., Stankiewicz-Mróz, A., 2005. Wprowadzenie do organizacji i zarządzania. Oficyna Ekonomiczna Grupa Wolters Kluwer, Kraków, Poland.

Łukasiński, W. 2008. Zarządzanie jakością produktu ekologicznego. Żywność. Nauka, Technologia, Jakość, 1(56), 149-151.

Maszke, A., Dwornicka, R., Ulewicz, R., 2018. Problems in the Implementation of the Lean Concept at a Steel Works - Case Study. MATEC Web of Conferences 183, 01014.

Mazur M., Dziuba S., Weiss E., 2016. Zarządzanie jakością i bezpieczeństwem w przemyśle spożywczym. Oficyna Wydawnicza Stowarzyszenia Menedżerów Jakości i Produkcji, Częstochowa, Poland.

Oleksyn, T., 2010. Zarządzanie kompetencjami. Teoria i praktyka. Wolters Kluwer business, Warsaw, Poland.

Pietroń-Pyszczek, A., 2015. Motywowanie pracowników. Wskazówki dla menedżerów. Wyd. Marina, Wrocław, Poland.

Rakowska, A., 2007. Kompetencje menedżerskie kadry kierowniczej we współczesnych organizacjach. Wydawnictwo Uniwersytetu Marii CurieSkłodowskiej, Lublin, Poland.

Robles, M., 2012. Executive Perceptions of the Top 10 Soft Skills Needed in Today's Workplace. Business Communication Quarterly, 75, 4, 454-461.

Tate, W.L., Ellram, L.M., Bals, L., Hartmann E., 2009. Offshore outsourcing of services: An evolutionary perspective. International Journal of Production Economics, 120, 2, 512-524.

Wolniak, R., Skotnicka-Zasadzień, B., Gębalska-Kwiecień, A., 2018. Identification of bottlenecks and analysis of the state before applying lean management. MATEC Web of Conferences 183, 01001.

Womack, J.P, Jones, D.T., Roos, D., 1990. Machine that changed the world. Simon and Schuster, New York, USA.

Zivaljevic, A., 2015. Theory of constraints - application in land transportation systems. Management of Environmental Quality. An International Journal, 26, 4, 505-517. 